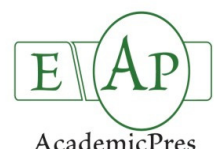

\title{
Seasonal Changes in Leaf Tissue Rehydration of One Annual and Two Perennial Grass Forage Species Induced by Bioclimate
}

\author{
Eirini - Ia KAPSALI, Maria KARATASSIOU* \\ Aristotle University of Thessaloniki, Department of Forestry and Natural Environment, Laboratory of Rangeland Ecology (286), 54124 Thessaloniki, \\ Greece;karatas@for.auth.gr("correspondingauthor)
}

\begin{abstract}
Bioclimate signifies the continuous interplay between plants and climate factors (primarily drought) and has a direct impact on the water relations and the duration of the rehydration process in water stressed plants. To explore the association between bioclimate and water physiology of forage species in semi-arid Mediterranean grasslands, we determined the seasonal variation in leaf water potential, turgid weight and relative water content in wild growing Dactylis glomerata L., Bromus inermis Leyss (perennial) and Bromus sterilis L. (annual) during the growing season. The study was conducted at the farm of the Aristotle University of Thessaloniki. The results of the current study reveal that $B$. sterilis maintained high levels of water potential most probably by accelerating its biological cycle and decreasing water content because it fails to sustain turgidity. Dactylis glomerata and B. inermis presented even higher water contents than B. sterilis for the same water potential. Dactylis glomerata exhibited substantially higher water potential and content than $B$. inermis by keeping the rehydration duration stable. The extensive creeping rhizome seems to allow $B$. inermis to sustain high values of water potential and content possibly ensuring turgidity. Regardless of the grass species the duration of rehydration ranged from 2.5 to 3.5 hours throughout the growing season. Our findings demonstrate that (a) D. glomerata and B. inermis are better adapted to Mediterranean semiarid conditions than B. sterilis and (b) turgid weight in Mediterranean forage species can safely be determined after a rehydration period of 3.5 hours.
\end{abstract}

Keywords: relative water content, turgid weight, semiarid grassland, water deficit, water potential

\section{Introduction}

Water in a natural vegetation is directly associated with environmental factors, especially climate (Trejo et al., 2011). The constant interaction between plant communities and climate factors is known as bioclimate (Vlachos, 2006; Savo et al., 2012). One of the most important climatic factors affecting plant viability is the annual amount and especially the annual distribution of precipitation. This is due to the physical and chemical properties of water, which render it essential for all physiological processes taking place in plants (Lambers et al., 2008). In fact, water availability is the main factor limiting plant growth and production during the growing season, and regulating plant diversity in an ecosystem (Henkin et al., 2010; Mitra et al., 2013).

Over the last few decades, major human interventions in the natural environment have brought significant changes to global climate (Trejo et al., 2011). In the aftermath of greenhouse effect intensification, the increase of average air temperature, along with the reduction and uneven distribution of precipitation have caused drought frequency and severity to become more intense (IPCC, 2007; Xu et al., 2010; Savo et al., 2012). Drought causes water deficit in plant tissues, which in turn leads to the disruption (stress) of their standard physiological and metabolic functions
(Kusaka et al., 2005). Mild water deficit induces a decline in plant growth rate, as a consequence of a decrease in cell turgidity and the restriction of photosynthesis. Severe water deficit results in the accumulation of osmolytes in plant tissues, the formation of air cavities in the conduit tissue, even the deconstruction of protoplasm, as plants reach the permanent wilting point (Aranjuelo et al., 2011). Water deficit mostly affects plants in arid and semiarid regions of the world (Wood, 2005), such as those lying along the coast of the Mediterranean Sea, where the drought (or xerothermic) period coincides with the growing season of many important forage species (Galmés et al., 2007; Savo et al., 2012).

Plants address severe xerothermic periods by employing certain adaptive mechanisms, which ensure survival by avoiding and/or tolerating drought (Karatassiou et al., 2009; Kostopoulou et al., 2010). These mechanisms include the development of both short-term and long-term adjustments in plant organisms, such as the emergence of specific phenotypic characteristics, and changes in anatomy and morphology, as well as physiology (Lambers et al., 2008; Hayano-Kanashiro et al., 2009; Blum, 2011). However, drought adaptation mechanisms may differ among plant species and genotypes (Mohsenzadeh et al., 2006; Norton et al., 2007; Aslam et al., 2013). Annual species (ephemerals) mainly use drought avoidance mechanisms that 
480

may be facilitated by phenotypic plasticity, in order to quickly complete their biological cycle so that occurrence and growth coincide with periods of abundant rainfall (Chaves et al., 2002; Moreno et al., 2008). Perennial species, on the other hand, may utilize both mechanisms of drought avoidance and/or tolerance (Volaire, 2008).

Drought adaptation mechanisms contribute greatly to the improvement of water relations in plants (Grzesiak et al., 2006) and to the preservation of relatively constant water content in plant tissues (Iannucci et al., 2002; Keyvan, 2010). Through the process of transpiration, soil water flows through plants and into the atmosphere, along a gradient of decreasing water potential that forms between the three components of Soil-PlantAtmosphere Continuum (Blum, 2011). Therefore, maintaining high water content and also high water potential values in plant tissues ensures plant growth and reproduction during a xerothermic period (Galmés et al., 2007; Rahimi et al.,2010).

There are two hydrodynamic parameters that demonstrate the magnitude of the resistance plants exhibit towards water deficit: leaf water potential $(\Psi)$ and Relative Water Content (RWC) (González and González-Vilar, 2003; Blum, 2005; Dong et al., 2011). Water potential reveals the level of water availability in a plant, thus its state of health (Wood, 2005). A force that has a large impact on water potential and leads plant tissues to lose water is Vapor Pressure Deficit (VPD), which signifies the transpirational demand of the atmosphere (Lambers et al., 2008). Relative water content represents the relationship between water deficit in plant tissues and the absolute amount of water needed for them to reach full turgidity (González and González-Vilar, 2003; Ganji Arjenaki et al., 2012). Hence, RWC values depict the relative volume of plant cells and reveal the extent of water deficit effects on a plant (Mohsenzadeh $e t$ al., 2006).

Moreover, drought adaptation mechanisms also enhance the ability of plants to achieve rehydration when the opportunity occurs (Siopongco et al., 2006). Rehydration process consists of two phases of water intake. In Phase I, a rapid passive absorption of water takes place, in order for the plant to replenish the water deficit in its tissues and reach turgidity. In Phase II, water intake continues at a very low rate that can hardly be defined. The Phase I can be completed in a relatively short period of time, which may vary depending on plant species and genotype, lasting from 2 to 4 hours (Chan and Fowler, 1992); however, turgid weight of stressed plant tissue can safely be determined only after a 24 -hour rehydration period (Barrs and Weatherley, 1962). Yet, the minimum duration of rehydration needed by Mediterranean grasses in order to achieve turgidity as well as its seasonal variation remains unknown.

Rehydration leads to the recovery of standard plant function, as it contributes to the restoration of water relations, the maintenance of photosynthetic efficiency and the reactivation of biological activity in plant tissues (Mitra $e t$ al., 2013). The recovery rate and its extent depend primarily on the intensity and duration of water deficit in plant tissues, on climatic conditions (precipitation, solar radiation) during present and especially past xerothermic periods (as they could have resulted in the restriction of meristem), on plant species, genotype, age, phenological stage of development and leaf structure, and also on the capacity for water intake that plants exhibit at the end of the drought period (Volaire et al., 1998; Chaves and Oliveira, 2004; Siopongco et al.,
2006; Blum, 2011). Bajii et al. (2000), Pinheiro et al. (2004), Miyashita et al. (2005) and Rahimi et al. (2010) report that the great intensity and duration of water deficit and the small amount of time given for rehydration restrict the recovery of water in annual species. The above studies demonstrate a wide range of $\Psi$ rescue (from $24 \%$ to $100 \%$ ). Yet there are annual species in which the rate of water recovery varied considerably depending on the species and genotype (Grzesiak et al., 2006; DaCosta and Huang, 2007; Izanloo et al., 2008; HayanoKanashiro et al., 2009). Similar effects of the intensity and duration of water deficit, and duration of rehydration on the recovery of water relations have been reported in perennial species (Awal and Ikeda, 2002; Mohsenzadeh et al., 2006; DaCosta and Huang, 2007; Xu et al., 2010). In these studies, RWC recovery ranged from $70 \%$ to $100 \%$.

This paper aimed at examining how bioclimate regulates the seasonal changes in rehydration duration of annual and perennial grasses. To address the above objective we studied (a) the effect of bioclimate on water relations of three grass forage species, (b) the variance of rehydration duration in annual and perennial grass forage species throughout their life cycle, and (c) the ecophysiological mechanisms that grass forage species employ to address bioclimate changes.

\section{Materials and Methods}

\section{Study area and climate}

The experiments were conducted on the natural vegetation at the farm of the Aristotle University of Thessaloniki (Northern Greece) (longitude: $40^{\circ} 31^{\prime} 91^{\prime \prime}$, latitude: $23^{\circ} 59^{\prime} 58^{\prime \prime}$, altitude: $6 \mathrm{~m}$ a.s.l.), during the growing season of 2011. The climate of the study area is characterized as Mediterranean semiarid with cold winters following the bioclimatogram of Emberger (Dafis, 1986), which is typical of the Mediterranean semiarid type (Emberger et al., 1963), with a mild meso-Mediterranean sub climate of cold winters, hot summers and a long dry period. The mean annual precipitation is $443 \mathrm{~mm}$, and the mean annual temperature is $15.5^{\circ} \mathrm{C}$.

The Vapor Pressure Deficit (VPD), air temperature (T) and relative humidity $(\mathrm{RH})$ were measured using a microclimatic sensor (Novasima MS1, Novatron Scientific Ltd, Horsham, $\mathrm{UK}$ ) during the period of measurements. The values of VPD, $\mathrm{RH}$ and T given are averages of six measurements that have been recorded on the date and time that plant physiological parameters were measured (Figs. 1 and 2). Details regarding the experimental plan and measurements taken are given below.

\section{Physiologicalmeasurements}

Leaf water potential $(\Psi)$, Relative Water Content (RWC) and Turgidity Weight (TW) were measured in two perennial grass species Dactylis glomerata L. and Bromus inermis Leyss and one annual grass species Bromus sterilis L. Both perennial species were chosen because they are important forage species in the low elevation Mediterranean grasslands, since they produce high quality forage during spring and early summer (Papanastasis and Karagiannakidou-Papadimitriou, 1983). The annual grass species was included in the study as a reference species in order to contrast its ecophysiological response (drought avoidance) against the two perennial species (drought avoidance and/or tolerance).

Seasonal measurements were performed on clear sunny days 
from 11:00am to $13: 00 \mathrm{pm}$ at approximately 15 -day intervals at the beginning of the growing season. As drought was becoming intense (middle-end of the growing season), measurements were conducted at short time intervals ranging from approximately 10 in the middle to 2 days at the end of the growing season. Two plants of each species were randomly selected along a 20-metre line. Three lines and a total of 6 plant species have been considered for each species (Cornelissen et al., 2003). All measurements were obtained from mature, intact and fully expanded upper leaves that were randomly selected from each species. In each day for each parameter, the values presented are averages of six plants.

Leaf water potential $(\Psi)$ was measured using the pressure chamber technique (Koide et al., 1991; González, 2003). Relative water content (RWC) and turgid weight (TW) were determined on $5 \mathrm{~mm}$ discs from leaves similar in age and orientation that came from the same plants that were used in measuring $\Psi$. The leaf discs were transferred to the laboratory where their fresh weights (FW) were determined in a saturated atmosphere. Subsequently, the discs were allowed to float in distilled water at $4-6^{\circ} \mathrm{C}$ for $24 \mathrm{~h}$, until they reached turgid weight (TW). The same disks were later dried at $70-80^{\circ} \mathrm{C}$ for a period of 24-48 h, and were weighed again, in order to determine dry weight (DW). Relative Water Content was calculated using the following formula: $R W C=\frac{F W-D W}{T W-D W} \times 100$ (Iannucci et al., 2002; González and González-Vilar, 2003).

Turgid weight (TW) of the leaf disks was also determined with the use of the improved relative turgidity technique by Barrs and Weatherley (1962). At first, the leaf disks were weighed directly in order to obtain the fresh weight. Afterwards, the disks were left to float in distilled water (fully saturated atmosphere) and remained in the dark, at a temperature of $4-6^{\circ} \mathrm{C}$. Every 30 min the disks were weighed until they were fully rehydrated and had reached a constant TW (Phase I of the rehydration process). The disks then remained floating in fully saturated atmosphere for $24 \mathrm{~h}$ and were ultimately reweighed to confirm their previously measured TW (Chan and Fowler, 1992).

\section{Statistical analysis}

In order to determine differences in the ecophysiological responses of the three species (first factor) during the growing season (second factor), we performed analysis of variance $(A N O V A)$ on all parameters studied, using the univariate general linear model (dependent variables: $\Psi$, RWC and TW), the multivariate general linear model (dependent variable $\Psi$ together with dependent variable RWC) and the bivariate (correlation) model (covariant $\Psi$ together with covariant VPD, covariant RWC together with covariant VPD). The standard error of all means was also calculated while the same analyses and significance level for all tests were set at $\alpha=0.05$ (Steel and Torrie, 1980). Following a significant one way $A N O V A$ that ran at each measurement date, for each parameter, means of the three species were separated with the Fisher's PLSD test $(\mathrm{p} \leq 0.05)$. All statistical analyses were carried out using the SPSS v. 22.0 statistical package (IBM Corp., Armonk, NY, USA).
Results

\section{Climatic conditions and water relations}

The drought (xerothermic) period in the experimental area began in late May 2011 and lasted until approximately mid autumn. Mean annual temperature was $14.9^{\circ} \mathrm{C}$ and annual precipitation reached $338 \mathrm{~mm}$. During the experimental period, mean monthly temperature and mean monthly precipitation ranged from $12.8^{\circ} \mathrm{C}$ (April 2011) to $26.9^{\circ} \mathrm{C}$ (July 2011), and from $73.90 \mathrm{~mm}$ (May 2011) to $0.51 \mathrm{~mm}$ (July 2011) respectively (Fig. 1).

Statistical analyses revealed significant differences among the three forage species $(\mathrm{p} \leq 0.0001)$ for all tested parameters $(\Psi$, RWC and TW). Time of measurements also influenced significantly $\Psi$, RWC and TW ( $\mathrm{p} \leq 0.0001)$. Moreover, the interaction between time of season (measurement) and species was significant $(p \leq 0.01)$, suggesting that the species examined exhibited different physiological responses to water deficit conditions.

During the experimental period VPD values gradually increased ( $\mathrm{p} \leq 0.0001$ ) from $0.78 \mathrm{kPa}$ in April 2011 to $2.06 \mathrm{kPa}$ in July 2011. $\Psi$ followed a declining trend in all species during the growing season, which for D. glomerata and B. inermis was facilitated by the negative correlation between VPD and $\Psi(\mathrm{r}=$ $0.524, \mathrm{p} \leq 0.05$ and $\mathrm{r}=-0.823, \mathrm{p} \leq 0.01$ respectively). Early in

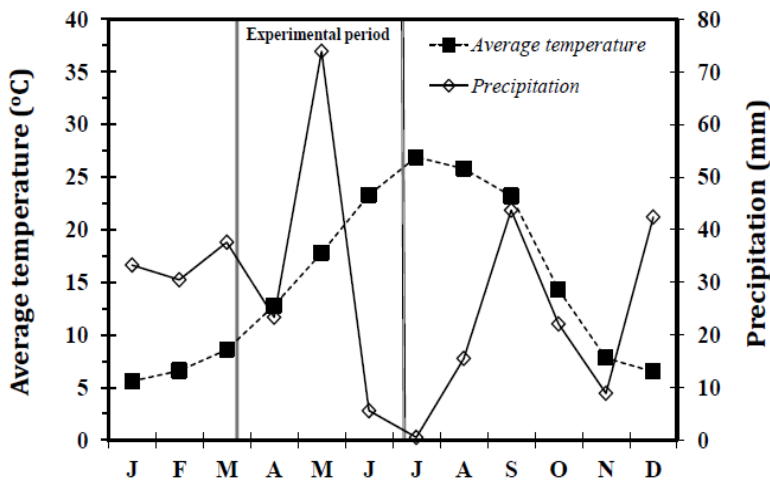

Fig. 1. Climatic diagram of the experimental area during 2011

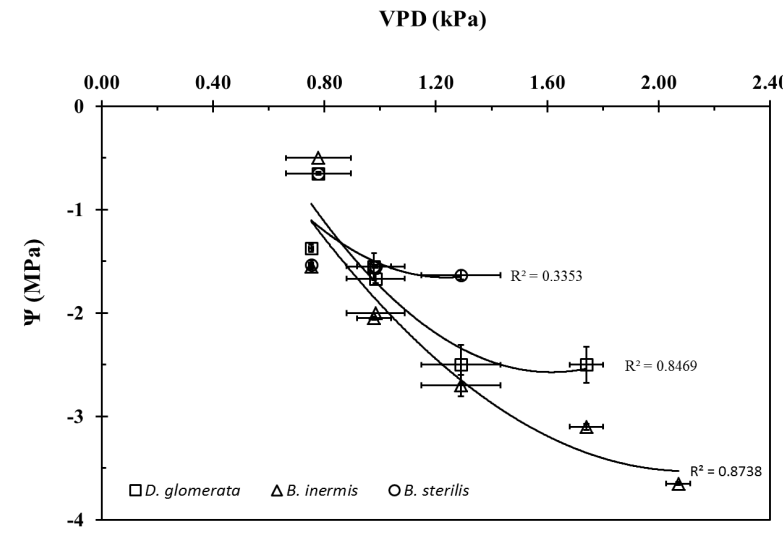

Fig. 2. The relationship between midday leaf water potential $(\Psi)$ and vapor pressure deficit (VPD) for Dactylis glomerata, Bromus inermis and Bromus sterilis. Values present means \pm SE $(\mathrm{n}=6)$ 
482

spring, when VPD was low, the three species presented approximately similar values of $\Psi$ (around $-0.60 \mathrm{MPa}$ ), with $B$. inermis expressing the highest value. However, $\Psi$ values differed among the species $(\mathrm{p} \leq 0.01)$ as the growing season progressed and VPD increased (Fig. 2).

The annual species $B$. sterilis presented a considerable decrease in $\Psi$ during the early vegetative stages, as opposed to flowering, when it exhibited little variation in $\Psi$ values. Bromus sterilis completed its biological cycle at the beginning of the xerothermic period in early June, at higher $\Psi(-1.63 \mathrm{MPa})$ values $(\mathrm{p} \leq 0.01)$ and earlier than the other two species (Fig. 3). As far as the two perennial species are concerned, D. glomerata expressed higher $\Psi$ values $(\mathrm{p} \leq 0.01)$ than $B$. inermis during the growing season. Specifically, D. glomerata presented an initial gradual decline in $\Psi$, followed by a temporal stabilization, which lasted from mid-May until the beginning of the xerothermic period. At the same time, $B$. inermis followed a similar course in $\Psi$, although having a steeper initial decrease than $D$. glomerata. As the xerothermic period progressed, $\Psi$ decreased dramatically in $D$. glomerata until its water status was finally stabilized $(-2.50 \mathrm{MPa})$ and preserved up to the end of the biological cycle in late June. Likewise, as the xerothermic period progressed, $\Psi$ greatly decreased in B. inermis thus expressing the lowest value of the three species studied (-3.65 MPa) (Fig. 3).

Relative water content followed a declining pattern in all species during the growing season. In $B$. inermis, this declining trend was facilitated by the existing negative correlation between RWC and VPD $(r=-0.466, p \leq 0.01)$. In early vegetative stages (April), substantial differences in RWC were detected among the three species $(\mathrm{p} \leq 0.001)$, with $B$. inermis presenting the highest (93.7\%) and B. sterilis the lowest (91.01\%) value. Bromus sterilis completed its biological cycle at a water deficit of $20.41 \%$. From mid-May to late June, D. glomerata exhibited significantly higher values of RWC $(\mathrm{p} \leq 0.001)$ than $B$. inermis. Later in the growing season, $D$. glomerata managed to complete the fruiting stage, during the xerothermic period, by presenting the lowest RWC of the growing season (73.6\%). Bromus inermis was able to continue its growth until water deficit reached a value of approximately $20 \%$ (Fig. 4) in the mid July.

The relationship between $\Psi$ and RWC reveals that at a high value of $\Psi$ (approximately -1.0 MPa), B. inermis presented the

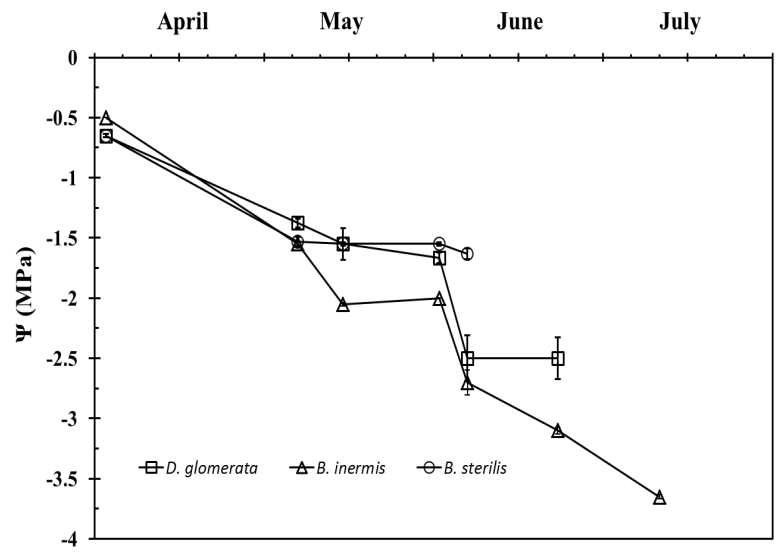

Fig. 3. Seasonal patterns of leaf water potential $(\Psi)$ in Dactylis glomerata, Bromus inermis and Bromus sterilis. Values present means \pm SE $(n=6)$

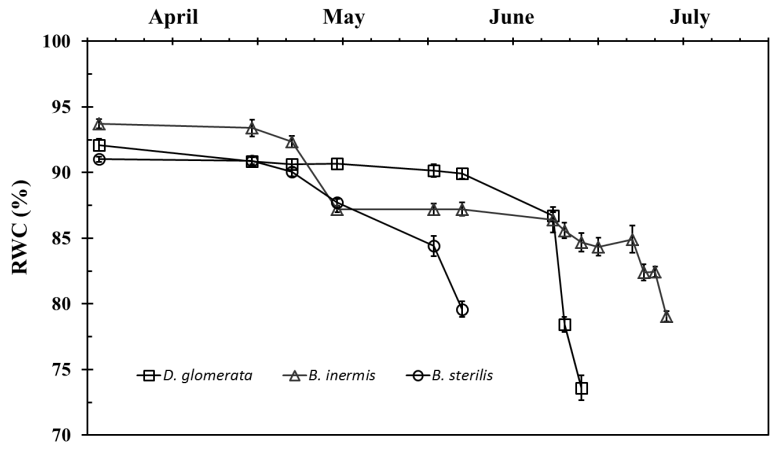

Fig. 4. Seasonal patterns of relative water content (RWC) in Dactylis glomerata, Bromus inermis and Bromus sterilis. Values present means \pm SE $(\mathrm{n}=6)$

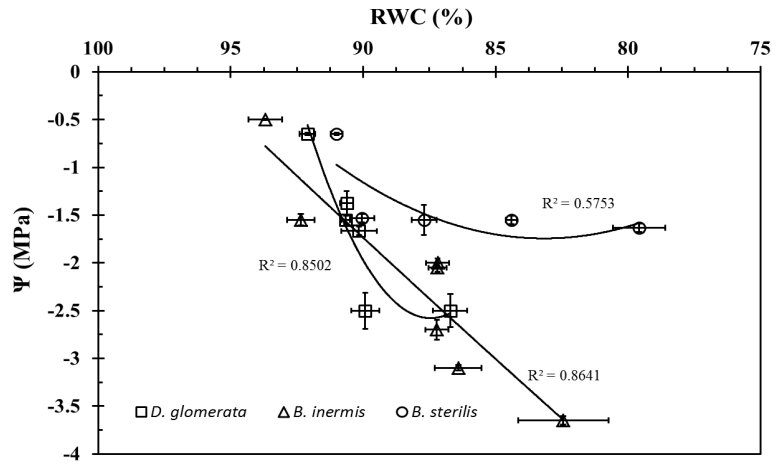

Fig. 5. Relationships between leaf water potential $(\Psi)$ and relative water content (RWC) for Dactylis glomerata, Bromus inermis and Bromus sterilis. Values present means \pm SE $(\mathrm{n}=6)$

highest RWC, followed by D. glomerata, while B. sterilis presented the lowest RWC. At lower values of $\Psi, D$. glomerata presented the highest RWC, while $B$. inermis showed a substantially lower RWC (Fig. 5).

\section{Rehydration -Floating time}

Dactylis glomerata generally kept higher relative water content ( $p \leq 0.001)$ (Fig. 4) and presented a much more stable rehydration (turgidity) during the growing season compared with the other two species (Figs. 6-9). The seasonal variation of rehydration duration in B. sterilis and B. inermis (Figs. 6-10) was generally consistent with the seasonal changes in their water content and water status (Figs. 3 and 4).

In April, when environmental conditions were favorable (average temperature $12.2^{\circ} \mathrm{C}, \mathrm{VPD} 0.78 \mathrm{kPa}$ ) (Fig. 1, 2) and the RWC of all species high (Fig. 4), B. inermis achieved turgidity sooner $(2.5 \mathrm{~h})$ than B. sterilis and D. glomerata (Fig. 6). The changes in leaf disk fresh weight over successive measurements were not affected by the grass species $p>0.05$ ). Floating time was a significant predictor of the changes in leaf disk fresh weight $(\mathrm{p} \leq$ $0.001)$. The interaction between plant species and floating time was not significant as well $(\mathrm{p}>0.05)$ indicating no differences in the rehydration duration among the three species.

During May, the high rate of precipitation $(73.9 \mathrm{~mm}) \mathrm{did}$ not interrupt the upward trend of VPD $(0.98 \mathrm{kPa})$ and the rise of temperature $\left(18.7^{\circ} \mathrm{C}\right)$, which in turn affected the relationship of $\Psi$ and RWC in all three species. Plant species had no significant effect on the changes in leaf fresh weight $(p>0.05)$, 
contrary to floating time $(\mathrm{p} \leq 0.001)$. The interaction between plant species and floating time was also significant $(\mathrm{p} \leq 0.05)$ highlighting variations in the rehydration duration among the three species. The perennial species D. glomerata and B. inermis were fully rehydrated after 3.5 hours in mid-May, while the annual species $B$. sterilis maintained rehydration duration stable during the growing season (Fig. 7).

At the beginning of the xerothermic period (early June), the grass species was not a significant predictor of the changes in leaf disk fresh weight over successive measurements $(p>0.05)$ but floating time was $(\mathrm{p} \leq 0.001)$. The interaction between plant species and floating time was also significant ( $p \leq 0.001$ ) suggesting variations in the rehydration duration among the three species. Both $B$. sterilis and $B$. inermis expressed reduced rehydration duration (Fig. 8), although water deficit was increased; average temperature in June ranged from approximately $20^{\circ} \mathrm{C}$ to $25^{\circ} \mathrm{C}$, while precipitation was $5.59 \mathrm{~mm}$ and $V P D$ reached $1.71 \mathrm{kPa}$.

However, as water deficit intensified from late June to midJuly due to extreme temperatures $\left(26.9^{\circ} \mathrm{C}\right)$, low precipitation $(0.55 \mathrm{~mm})$ and the amplification of VPD $(2.01 \mathrm{kPa})$, the changes in leaf disk rehydration weight over successive measurements were not influenced by the grass species $(\mathrm{p}>$ 0.05 ). Floating time had a significant effect on the changes in leaf disk rehydration weight $(\mathrm{p} \leq 0.001)$. The interaction between plant species and floating time was significant as well ( $\mathrm{p} \leq 0.001)$

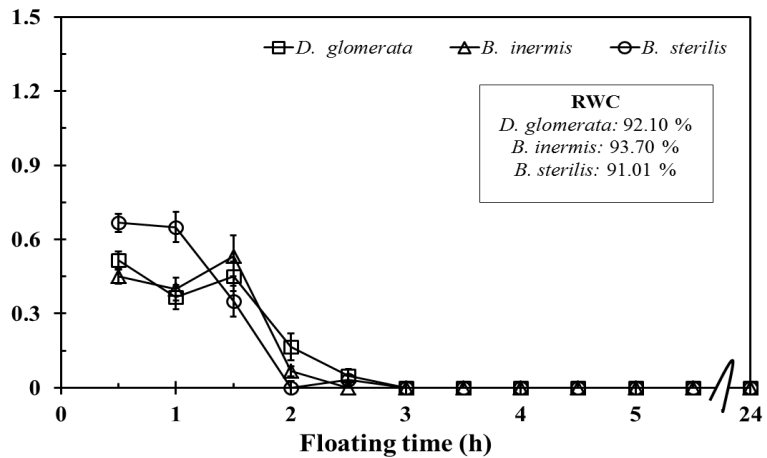

Fig. 6. Fresh weight changes (grX1000) of floating leaf disks obtained from Dactylis glomerata, Bromus inermis and Bromus sterilis as a function of time in April. Values present means \pm $\operatorname{SE}(\mathrm{n}=6)$

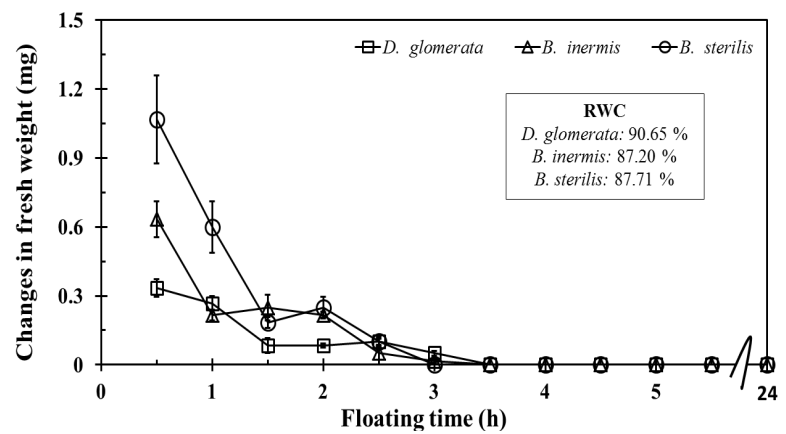

Fig. 7. Fresh weight changes (grX1000) of floating leaf disks obtained from Dactylis glomerata, Bromus inermis and Bromus sterilis as a function of time in mid-May. Values present means $\pm \operatorname{SE}(\mathrm{n}=6)$ suggesting variations in the rehydration duration between the two perennial species. Bromus inermis required more time to restore its water losses during the fruiting stage, completing its biological cycle in the middle of the xerothermic period with maximum rehydration duration of $3.5 \mathrm{~h}$ (Figs. 9 and 10 ).

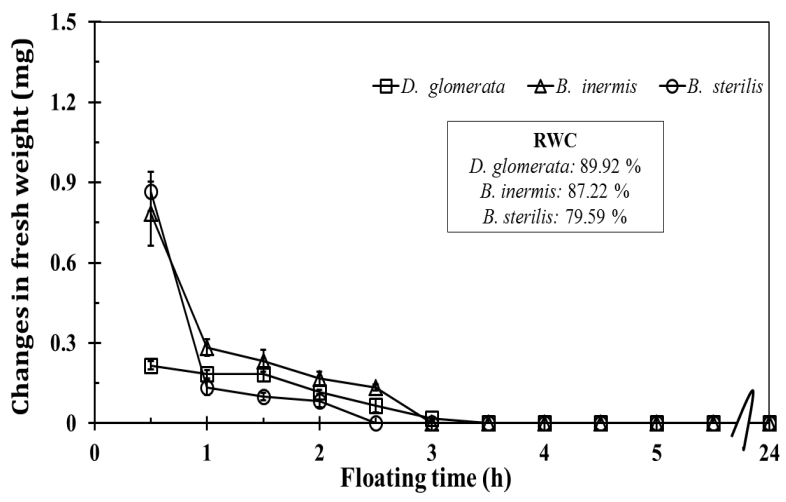

Fig. 8. Fresh weight changes (grX1000) of floating leaf disks obtained from Dactylis glomerata, Bromus inermis and Bromus sterilis as a function of time at the beginning of the xerothermic period (early June). Values present means \pm SE (n $=6$ )

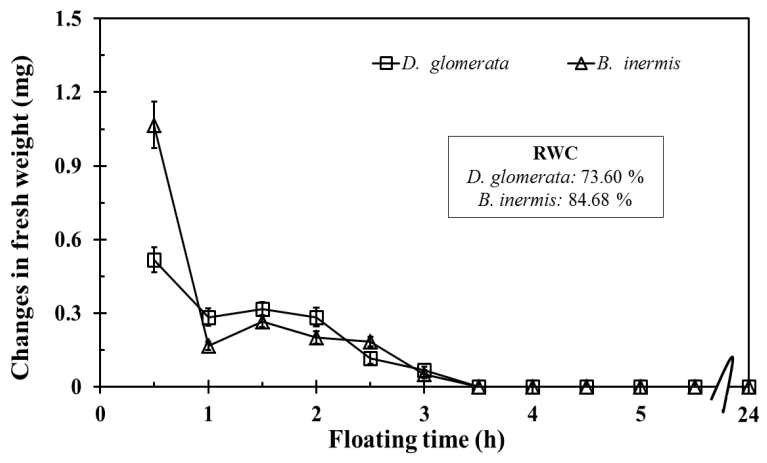

Fig. 9. Fresh weight changes (grX1000) of floating leaf disks obtained from Dactylis glomerata, Bromus inermis and Bromus sterilis as a function of time at the middle of the xerothermic period (late June). Values present means \pm SE $(n=6)$

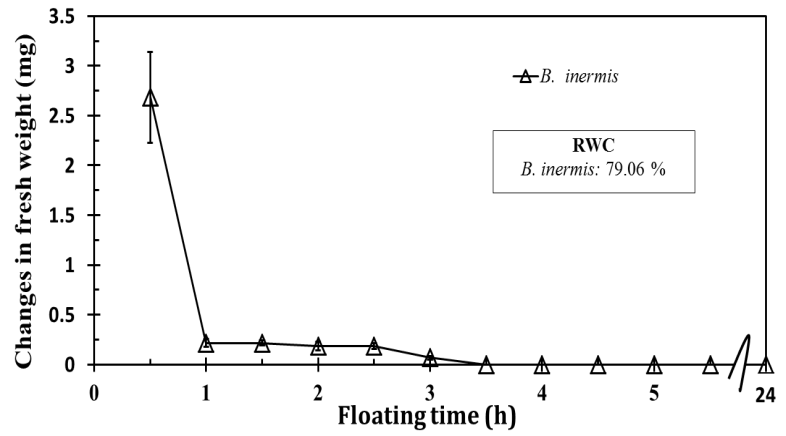

Fig. 10. Fresh weight changes (grX1000) of floating leaf disks obtained from Dactylis glomerata, Bromus inermis and Bromus sterilis as a function of time at the middle of the xerothermic period (mid-July). Values present means \pm SE $(n=6)$ 
484

\section{Discussion}

In the study area, plant vegetative and flowering stages coincide with the xerothermic period. During the experimental period, the rise in average temperature and the simultaneous reduction in the amount of precipitation led to a gradual increase in vapor pressure deficit (VPD) (Figs. 1 and 2), especially in late spring and early summer. Our results are similar to Galmés et al. (2007) and Lambers et al. (2008). Elevated VPD equals increased demands in transpiration, which induce an extensive water loss by plants, a considerable reduction in available soil water and the establishment of intense water deficit in plant tissues (González and Reigosa, 2003; Chaves and Oliveira, 2004). The effect of elevated VPD on the water status of the three species studied was confirmed by the seasonal changes in both leaf water potential $(\Psi)$ (Fig. 3) and relative water content (RWC) (Fig. 4).

In general, the three species considered in our study presented different physiological responses to water deficit conditions. During the growing season, the seasonal variance in $\Psi$ (Fig. 2,3) revealed a continuous variance in the water status of the three species, which must have strongly affected their growth. The variance in $\Psi$ among the three species could be due to differential adaptation and survival capacity under water deficit conditions (Chaves et al., 2002; Ganji Arjenaki et al., 2012). At the end of its biological cycle, the annual forage species B. sterilis presented a higher $\Psi$ than the perennial species (Fig. 3). Similar results were obtained by Volaire (2003), who report that the annual forage species Hordeum vulgare completed its life cycle at a higher $\Psi$ than the perennial species $D$. glomerata. Also Galmés et al. (2007) indicate that, compared to other perennial species, the annual forage species Diplotaxis ibicensis managed to maintain a higher $\Psi$ during the final stages of its biological cycle. The maintenance of a higher $\Psi$ value suggests that $B$. sterilis must have employed specific mechanisms in order to cope with drought conditions (Kusaka et al., 2005; Aslam et al., 2013).

As far as the perennial species are concerned, D. glomerata presented low $\Psi$ values during the xerothermic period (Fig. 3), due to the negative correlation between its $\Psi$ and VPD. Volaire and Lelièvre (2001) found that other genotypes of D. glomerata, which are more drought resistant (Currie, Medly and Lutetia), presented even lower $\Psi$ values. During the same period, $B$. inermis expressed the lowest $\Psi$ of all species studied (Fig. 3), results that concur with the negative correlation existing between VPD and $\Psi$ for this species and also with those obtained by Karatassiou et al. (2011). Low $\Psi$ can be consistent either with a high rate of transpiration and/or a restricted water intake and/or low hydraulic conductivity in plants (Iannucci et al., 2002; Moreno et al., 2008).

The seasonal pattern of RWC in the three species studied (Figs. 4 and 5) gives a more complete picture of their water status. During the growing season, the declining trend of RWC (Fig. 4) was proportional to the gradual increase of water deficit in the tissues of the three species (Keyvan, 2010). However, the three species exhibited varying RWC values (Fig. 4), as a result of their distinct ability to sustain stable water contents (Mamolos et al., 2001). Towards the beginning and in the middle of the xerothermic period, when weather conditions became acute (Figs. 1 and 2), RWC was reduced in all species (Fig. 4) as a result of their lack of rehydration, which may be caused by the seasonal reduction in the available soil water (Machado and Paulsen,
2001; Mohsenzadeh et al., 2006). With increasing water deficit, species maintaining higher water content are considered to be more drought-resistant (Keyvan, 2010; Ganji Arjenaki et al., 2012). There are several $D$. glomerata genotypes that can withstand even higher water deficits (Volaire, 2003). Bromus inermis, on the other hand, can maintain its water status unaffected for a long period of time (Karatassiou et al., 2011).

The relationship between $\Psi$ and RWC (Fig. 5) confirms that the three species have a diverse ability of water deficit resistance (Iannucci et al., 2002). Higher $\Psi$ and RWC values were determined in all species at the beginning of the experimental period (Fig. 3, 4, 5), when there was a considerable amount of soil water available for the plants (Fig. 1) (Lambers et al., 2008; Dong et al., 2011) and also due to low VPD (Fig. 2). On the contrary, lower $\Psi$ and RWC values were recorded at the end of the growing season (Figs. 3, 4, 5), probably due to increased transpiration and the reduction of plant cell turgidity (Chimenti et al., 2006).

Distinct responses to drought were observed between the annual $B$. sterilis and the perennial species, as expected, as well as between the two perennial species. As an annual $\mathrm{C}_{3}$ species, $B$. sterilis grows and develops when weather conditions are favorable and ceases growing when water deficit becomes intense (Mohsenzadeh et al., 2006; Karatassiou and Noitsakis, 2010). This is due to the fact that annual species exploit available soil water better in early spring, when there is less competition from other species (Moreno et al., 2008; Galmés et al., 2007). During the growing season, $B$. sterilis presented the smallest decrease in $\Psi$ (Fig. 3, 5) and the largest decrease in RWC (Figs. 4 and 5) compared to the perennial species, highlighting its inability to achieve adequate rehydration and to preserve a good water status (Volaire, 2003).

The perennial species were less affected by water deficit since they maintained growth and development until mid-summer, supposedly by making a better use of the limited available soil water during early flowering, at the beginning of the xerothermic period (Awal and Ikeda, 2002). Plants that preserve good and relatively constant water content at low $\Psi$ values are deemed capable of handling water deficit better and maintaining usual growth rate (Blum, 2005; Volaire, 2008; Rahimi et al., 2010). The occurrence of low values of RWC for the same low values of $\Psi$ (Fig. 5) means that $B$. inermis was less adequate to manage water deficit than $D$. glomerata.

Further analysis of the hydrodynamic parameters during the growing season of the three forage species suggested that different adaptation mechanisms (avoidance and tolerance) were deployed to deal with water deficit. These adaptation mechanisms protected plants from the adverse effects of water deficit and enhanced their survival chances; they contributed to the achievement and maintenance of high water content in plant tissues both during and after the xerothermic period, while they satisfactorily facilitated the continuation of plant growth (Chaves et al., 2002; Blum, 2005; Hayano-Kanashiro et al., 2009). The annual species $B$. sterilis completed growth and reached flowering and fruiting in a short time, supposedly by accelerating its biological cycle in order to avoid intense water deficit (Bajji et al., 2000; Machado and Paulsen, 2001; Galmés et al., 2007).

Dactylis glomerata responded well to water deficit by being capable of forming a sufficient water status in its tissues. This was 
probably achieved through the deep root system that this species often develops in order to extract water from deeper soil layers (Chaves and Oliveira, 2004). Its adequate root volume possibly reinforced soil water intake (Kusaka et al., 2005; Xu et al., 2010; Aslam et al., 2013), enabling D. glomerata to maintain $\Psi$ and RWC stable for longer periods of time. Volaire and Lelièvre (2001) also observed high water content values in three droughtresistant genotypes of $D$. glomerata, which had developed an extensive root system. However, Kostopoulou et al. (2010) point out that a rangeland ecotype of this species managed to avoid intense dehydration by reducing transpiration losses through the restriction of stomatal aperture. At the beginning of the xerothermic period, though presenting a higher RWC than the other species, D. glomerata exhibited signs of early drying. Norton et al. (2007) mark that in order to tolerate water deficit certain genotypes of $D$. glomerata coming from semiarid or arid regions often express a level of summer dormancy. Volaire (2003, 2008) confirmed that a drought-resistant D. glomerata genotype, presenting high $\Psi$ and RWC values, exploited the same mechanism in order to tolerate water deficit. So it is possible that the species studied here applied the same tolerance mechanism as well.

However, B. inermis had a different response towards water deficit than $D$. glomerata. The species initially maintained favorable water content in its tissues and presented high values of $\Psi$ and RWC (Figs. 3, 4, 5), probably by exploiting soil water reserves via its extended root system and extensive creeping rhizome (Karatasiou et al., 2011). However, when water deficit became intense, $B$. inermis possibly resisted drought through physiological adjustments, which include changes in cell wall elasticity and osmotic adjustment. These mechanisms help stressed plants maintain leaf turgidity, even when RWC is quite low (Mamolos et al., 2001; González and Reigosa Roger, 2003; Pinheiro et al., 2004; Dong et al., 2011).

\section{Rehydration - Floating time}

The time needed for the species to fully rehydrate fluctuated during growing season, as it was possibly affected by their genotype, stage of development, age, leaf structure, the observed climatic conditions (precipitation and solar radiation), the intensity and duration of water deficit and the water intake capability exhibited by the species (Siopongco et al., 2006; DaCosta and Huang, 2007). Rehydration duration did not vary greatly among the species during early vegetative stages (Fig. 6), when environmental conditions were favorable (Figs. 1 and 2). Nevertheless, $B$. inermis achieved turgidity sooner than the other two species (Fig. 6). Grzesiak et al. (2006) report similar results for Triticale sp. and Zea mays, which developed differential rehydration ability after being exposed to a short-term water deficit, by applying distinct adaptation mechanisms.

In mid-May, despite precipitation events, the perennial species needed more time to replenish water losses (Fig. 7); because of increased temperatures and VPD (Figs. 1 and 2), which led to the intensification of water deficit in plant tissues (Blum, 2005). However, rehydration duration was more extended in B. inermis (Fig. 7), suggesting that the increased VPD (Fig. 2) affected the ability of the species to maintain a favorable water content under intense water deficit (Izanloo et al., 2008), a fact that was confirmed by the significant negative correlation found between VPD and RWC of the species.
At the beginning of the xerothermic period, although VPD and water deficit increased significantly (Fig. 2), B. sterilis kept rehydration duration relatively short (Fig. 8) probably by using its root system to absorb recent water reserves on the soil surface (Chaves et al., 2002). Bromus inermis also managed to reduce rehydration duration (Fig. 8) by temporarily stabilizing its water content (Fig. 4) (Oliver et al., 1998; Karatassiou et al., 2009; Xu et al., 2010), through a decrease in $\Psi$ (Fig. 3), possibly by the application of osmotic regulation (González and Reigosa Roger, 2003; Keyvan, 2010). At the same time, D. glomerata stabilized rehydration duration but failed to limit RWC decline (Fig. 4). This fact indicates that, at the final stages of its biological cycle, the species most likely did not succeed in fully saturating its tissues and recovering its normal function due to the onset of the decomposition of cell walls, the formation of air cavities in conduit tissue, and even the degradation of protoplasm (Bartoli et al., 1999). Mohsenzadeh et al. (2006) demonstrate that the perennial forage species Aeluropus lagopoides also failed to recover fully from the intense water deficit through rehydration. Similar results were obtained by Galmés et al. (2007), who state that the 24-h rehydration of the intensely water-stressed perennial species Beta maritima ssp. maritima and Beta maritima ssp. macrosii only led to a partial (70-80\%) recovery of their water relations.

In the middle of the xerothermic period (Fig. 9), the extensive drought greatly hindered the recovery of water relations in the two perennial species (Figs. 4 and 5). As D. glomerata exhibited early drying signs, it is possible that it went into a state of dormancy during the last stage of its development (Chaves et al., 2002; Blum, 2005; Mitra et al., 2013). Unlike D. glomerata, $B$. inermis continued growing and producing under intense water deficit (Kapsali 2014). In order to prolong its development up to this point, $B$. inermis supposedly applied the appropriate adaptation mechanisms towards intense water deficit, such as osmotic regulation, which distinguishes the more droughtresistant species (Volaire, 2003; Kusaka et al., 2005; Chimenti et al., 2006; Izanloo et al., 2008; Ganji Arjenaki et al., 2012).

\section{Conclusions}

In the Mediterranean region, bioclimate greatly affects water relations and the duration of rehydration process in forage species that are common in semiarid grasslands. Both leaf water potential $(\Psi)$ and relative water content (RWC) varied greatly between the annual and perennial species studied, as well as between the two perennial species, revealing distinct physiological responses and the use of different adaptation mechanisms towards water deficit conditions. On the contrary, rehydration duration showed a limited variation among the three species, ranging from 2.5 hours during the first phenological stages to 3.5 hours during the xerothermic period. Bromus sterilis avoided intense water deficit conditions possibly by the acceleration of its biological cycle, which helped the species preserve its water status at a high level though it seems to have hindered its ability to maintain turgidity. D. glomerata and to a lesser extent $B$. inermis managed to maintain a favorable water balance under xerothermic Mediterranean conditions through physiological and/or morphological mechanisms and it is safe to determine their turgid weight after a rehydration period of four hours. 


\section{References}

Aranjuelo I, Moler G, Erice G, Avice JC, Salvador Nogués S (2011). Plant physiology and proteomics reveals the leaf response to drought in alfalfa (Medicago sativa L.).Journal of Experimental Botany 62(1):111-123.

Aslam M, Maqbool MA, Zaman QU, Latif MZ, Ahmad RM (2013). Responses of mungbean genotypes to drought stress at early growth stages. International Journal of Basic and Applied Sciences 13(5):22-27.

Aranjuelo I, Moler G, Erice G, Avice JC, Salvador Nogués S (2011). Plant physiology and proteomics reveals the leaf response to drought in alfalfa (Medicagosativa L.).Journal of Experimental Botany 62(1):111-123.

Aslam M, Maqbool MA, Zaman QU, Latif MZ, Ahmad RM (2013). Responses of mungbean genotypes to drought stress at early growth stages. International Journal of Basic and Applied Sciences 13(5):22-27.

Barrs HD, Weatherley PE (1962). A re-examination of the relative turgidity technique for estimating water deficits in leaves. Australian Journal of Biological Sciences 15:413-428.

Bartoli CG, Simontacchi M, Tambussi E, BeltranoJ, Montaldi E, Puntarulo $S$ (1999). Drought and watering-dependent oxidative stress: effect on antioxidant content in Triticum aestivum L. leaves. Journal of Experimental Botany 50(332):375-383.

Blum A (2005). Drought resistance, water-use efficiency, and yield potential are they compatible, dissonant, or mutually exclusive? Australian Journal of Agricultural Research 56:1159-1168.

Blum A (2011). Plant Water Relations, Plant Stress and Plant Production. In: Blum A (Ed). Plant Breeding for Water-Limited Environments. Springer-Verlag, New York pp 11-52.

Chan JL, FowlerJL (1992). Validation of relative water content for studying plant water relations in crambe. Industrial Crops and Products 1:21-29.

Chaves MM, Oliveira MM (2004). Mechanisms underlying plant resilience to water deficits: prospects for water-saving agriculture. Journal of Experimental Botany, Water-Saving in Agriculture Special Issue 55(407):2365-2384.

Chaves MM, Pereira JS, Maroco J, Rodriguez ML, Ricardo CPP, Osório ML, Carvalho I, Faria T, Pinheiro C (2002). How plants cope with water stress in the field. Photosynthesis and growth. Annals of Botany 89:907-916

Chimenti CA, Marcantonio M, Hall AJ (2006). Divergent selection for osmotic adjustment results in improved drought tolerance in maize (Zea mays L.) in both early growth and flowering phases. Field Crops Research 95:305-315.

Cornelissen JHC, Lavorel S, Garnier E, Díaz S, Buchmann N, Gurvich DE, Reich PB, ter Steege H, Morgan HD, van der Heijden MGA, Pausas JG, Poorter H (2003). A handbook of protocols for standardised and easy measurement of plant functional traits worldwide. Australian Journal of Botany 51:335-380.

DaCosta M, Huang B (2007). Drought survival and recuperative ability of bentgrass species associated with changes in abscisic acid and cytokinin production. Journal of the American Society for Horticultural Science 132(1):60-66.

Dafis S (1986). Forest Ecology (in Greek). Giahoudis-Giapoulis, Thessaloniki.

Dong X, Patton B, Nyren P, Limb R, Cihacek L, Kirby D, Deckard E (2011). Leaf-water relations of a native and an introduced grass species in the mixed-grass prairie under cattle grazing. Applied Ecology and Environmental Research 9(4):311-331.

Emberger L, Gaussen H, Kassas M, dePhilippis A (1963). Bioclimatic map of the Mediterranean zone, Ecological study of the Mediterranean zone, explanatory notes AridZone research 21.UNESCO-FAO, Paris.

Galmés J, Flexas J, Savé R, Medrano H (2007). Water relations and stomatal characteristics of Mediterranean plants with different growth forms and leaf habits: responses to water stress and recovery. Plant Soil 290:139155 .

Ganji Arjenaki F,Jabbari R, Morshedi A (2012). Evaluation of drought stress on Relative Water Content, chlorophyll content and mineral elements of wheat (Triticum aestivum L.) varieties. International Journal of Agriculture and CropSciences 4(11):726-729.

González L (2003). Determination of water potential in leaves. In: Reigosa Roger MJ (Ed). Handbook of Plant Ecophysiology Techniques. Kluwer Academic Publishers, New York, Boston, Dordrecht, London, Moscow pp 193-205.

González L, González-Vilar M (2003). Determination of relative water content. In: Reigosa Roger MJ (Ed). Handbook of Plant Ecophysiology Techniques. Kluwer Academic Publishers, New York, Boston, Dordrecht,London, Moscow pp 207-212.

González L, Reigosa Roger MJ (2003). Plant water status. In: Reigosa Roger MJ (Ed). Handbook of Plant Ecophysiology Techniques. Kluwer Academic Publishers, New York, Boston, Dordrecht, London, Moscow pp 185-191.

Grzesiak MT, Grzesiak S, Skoczowski A (2006). Changes of leaf water potential and gas exchange during and after drought in triticale and maize genotypes differing in drought tolerance. Photosynthetica 44(4):561-568.

Hayano-Kanashiro C, Calderón-Vázquez C, Ibarra-Laclette E, HerreraEstrella L, Simpson J (2009). Analysis of gene expression and physiological responses in three Mexican maize landraces under drought stress and recovery irrigation. PLoSONE4(10):1-19.

Henkin Z, Perevolotsky A, Sternberg M (2010). Vulnerability of Mediterranean grasslands to climate change: What can we learn from a long-term experiment? Options Méditerranéennes, Series A 92:167174.

Iannucci A, Russo M, Arena L, Di Fonzo N, Martiniello P (2002). Water deficit effects on osmotic adjustment and solute accumulation in leaves of annual clovers. European Journal of Agronomy 16:111-122.

IPCC (Intergovermental Panel on Climate Change) (2007). Climate Change 2007: The Physical Science Basis. In: Solomon S, Qin D, Manning M, Chen Z, Marquis M, Averyt KB, Tignor M, Miller HL (Eds). Contribution of Working Group I to the Fourth Assessment Report of the Intergovernmental Panel on Climate Change. Cambridge University Press, Cambridge and New York.

Izanloo A, Condon AG, Langridge P, Tester M, Schnurbusch T (2008). Different mechanisms of adaptation to cyclic water stress in two South Australian bread wheat cultivars. Journal of Experimental Botany 59(12):3327-3346.

Kapsali EI (2014). Seasonal changes in leaf tissue rehydration of forage species induced by bioclimate. MSc Dissertation (in Greek, with English summary), Department of Forestry and Natural Environment, Aristotle University of Thessaloniki. 
Karatassiou M, Kostopoulou P, Poliviou M, Kyprianou X (2011). Ecophysiological approach of drought tolerance of three grass species (in Greek, with English summary). In: Christodoulou A, Blioumis B, Stamatellos G (Eds). Scientific book of the School of Forestry and Natural Environment, Volume ME/2002/45. Aristotle University of Thessaloniki.

Karatassiou M, Noitsakis B (2010). Changes of the photosynthetic behaviour in annual $\mathrm{C}_{3}$ species at late successional stage under environmental drought conditions. Photosynthetica 48(3):377-382.

Karatassiou M, Noitsakis B, Koukoura Z (2009). Drought adaptation ecophysiological mechanisms of two annual legumes on semi-arid Mediterranean grassland. Scientific Research and Essay 4(5):493-500.

Keyvan S (2010). The effects of drought stress on yield, relative water content, proline, soluble carbohydrates and chlorophyll of bread wheat cultivars.Journal of Animal and Plant Sciences 8(3):1051-1060.

Koide RT, Robichaux RH, Morse SR, Smith CM (1991). Plant water status, hydraulic resistance and capacitance. In: Pearcy RW, Ehleringer JR, Mooney HA, Rundel RW (Eds). Plant Physiological Ecology: Field Methods and Instrumentation. Chapman and Hall,New Yorkpp 161183.

Kostopoulou P, Karatassiou M, Abraham EM, Parissi ZM, Kyriazopoulos A, Kapsali EI (2010). Ecophysiological responses of two ecotypes of Dactylis glomerata L. under water-deficit conditions. Options Méditerranéennes Series A 92:161-164.

Kusaka M, Lalusin AG, Fujimura T (2005). The maintenance of growth and turgor in pearl millet (Pennisetum glaucum L. Leeke) cultivars with different root structures and osmo-regulation under drought stress. Plant Science 168:1-14.

Lambers H, Chapin III FS, Pons TL (2008). Plant Physiological Ecology (2 Ed.).Springer,New York.

Machado S, Paulsen GM (2001). Combined effects of drought and high temperature on water relations of wheat and sorghum. Plant and Soil 233:179-187.

Mamolos AP, Veresoglou DS, Noitsakis V, Gerakis A (2001). Differential drought tolerance of five coexisting plant species in Mediterranean lowland grasslands. Journal of Arid Environments 49:329-341.

Mitra J, Xu G, Wang B, Li M, Deng X (2013): Understanding desiccation tolerance using the resurrection plant Boea hygrometrica as a model system. Frontiers in Plant Science, Plant Physiology 4(446):1-10.

Miyashita K, Tanakamaru S, Maitani T, Kimura K (2005). Recovery responses of photosynthesis, transpiration, and stomatal conductance in kidney bean following drought stress. Environmental and Experimental Botany 53:205-214.

Mohsenzadeh S, Malboobi MA, Razavi K, Farrahi-Aschtiani S (2006). Physiological and molecular responses of Aeluropus lagopoides (Poaceae) to water deficit. Environmental and Experimental Botany 56:314322.

Moreno M, Gulías J, Lazaridou M, Medrano H, Cifre J. (2008). Ecophysiological strategies to overcome water deficit in herbaceous species under Mediterranean conditions. Options Mèditeranèennes 79:247-256.

Norton M, Volaire F, Fukai S, Lelièvre F (2007). Summer dormancy - a drought resistance strategy in perennial grasses. In: Proceedings of the $22^{\text {nd }}$ Annual Conference of the Grassland Society of NSW. Pasture
Systems: Managing for a Variable Climate. Queanbeyan. ACT. Grassland Society of NSW Inc pp 58-59.

Oliver MJ, Wood AJ, O’Mahony P (1998). "To dryness and beyond" preparation for the dried state and rehydration in vegetative desiccationtolerant plants. Plant Growth Regulation 24:193-201.

Papanastasis VP, Karagiannakidou-Papadimitriou K (1983). The most important grasses of natural grasslands (in Greek). Greek Agricultural Ministry, Athens.

Pinheiro C, Passarinho JA, Ricardo CP (2004): Effect of drought and rewatering on the metabolism of Lupinus albus organs. Journal of Plant Physiology 161:1203-1210.

Rahimi A, Madah Hosseini S, Pooryoosef M, Fateh I (2010). Variation of leaf water potential, relative water content and SPAD under gradual drought stress and stress recovery in two medicinal species of Plantago ovata and P.psyllium. Plant Ecophysiology 2:53-60.

Savo V, De Zuliani E, Salvati L, Perini L, Caneva G (2012). Long-term changes in precipitation and temperature patterns and their possible impacts on vegetation (Tolfa-Cerite area, Central Italy). Applied Ecology andEnvironmental Research 10(3):243-266.

Siopongco JDLC, Yamauchi A, Salekdeh H, Bennett J, Wade LJ (2006). Growth and water use response of doubled-haploid rice lines to drought and rewatering during the vegetative stage. Plant Production Science 9(2):141-151.

Steel RGD, Torrie JH. (1980). Principles and Procedures of Statistics (2 ${ }^{\text {nd }}$ Ed).McGraw-Hill,New York.

Trejo I (2011). Analysis of the effects of climate change on plant communities and mammals in México. Atmósfera 24(1):1-14.

Vlachos A (2006). Flora, vegetation and ecology of the mountainous complex of Vardousia. PhD Thesis (in Greek, with English summary), Department of Biology, University of Patras, Greece.

Volaire F (2008). Plant traits and functional types to characterize drought survival of pluri-specific perennial herbaceous swards in Mediterranean areas. European Journal of Agronomy 29:116-124.

Volaire $F$ (2003). Seedling survival under drought differs between an annual (Hordeum vulgare) and a perennial grass (Dactylis glomerata). New Phytologist 160:501-510.

Volaire F, Lelièvre F (2001). Drought survival in Dactylis glomerata and Festuca arundinacea under similar rooting conditions in tubes. Plant and Soil 229:225-234.

Volaire F, Thomas H, Bertagne N, Bourgeois E, Gautier MF, Lelièvre F (1998): Survival and recovery of perennial forage grasses under prolonged Mediterranean drought. II. Water status, solute accumulation, abscisic acid concentration and accumulation of dehydrin transcripts in bases of immature leaves. New Phytologist 140:451-460.

Wood AJ (2005). Eco-physiological adaptations to limited water environments. In: Jenks MA, Hasegava PM (Eds). Plant Abiotic Stress. Blackwell Publishing Ltd, Oxford, UK doi: 10.1002/9780470988503.ch1.

Xu Z, Zhou G, Shimizu H (2010). Plant responses to drought and rewatering. Plant Signaling and Behavior 5(6):649-654. 